\title{
Digital radiopacity measurement of different resin- and zinc oxide-based root canal sealers
}

\author{
Mensuração digital da radiopacidade de diferentes cimentos \\ obturadores resinosos e de base zinco-enólica
}

\begin{abstract}
Purpose: To evaluate the radiopacity produced by seven commercially available (AH Plus, Epiphany, Sealapex, Acroseal, Sealer 26, Endomethasone and Endofill) and one experimental (MBP) root canal sealers.

Methods: Sealer radiopacity testing was performed according to ANSI/ADA Specification No. 57. Specimens were radiographed with an aluminum stepwedge, and the resulting images were digitalized. Radiographic densities expressed in Aluminum mm (mm Al) were compared using an ANOVA and Tukey's test $(\alpha=0.05)$.

Results: AH Plus (10 mm Al) and Epiphany $(9.0 \mathrm{~mm} \mathrm{Al})$ were the most radiopaque root canal sealers, followed by Sealapex ( $8 \mathrm{~mm} \mathrm{Al})$, Endofill $(7 \mathrm{~mm} \mathrm{Al})$, Endomethasone $(7 \mathrm{~mm} \mathrm{Al}), \mathrm{MBP}$ $(7 \mathrm{~mm} \mathrm{Al})$ and Sealer $26(6 \mathrm{~mm} \mathrm{Al})$. Acroseal $(5 \mathrm{~mm} \mathrm{Al})$ showed the smallest radiopacity among the tested sealers $(P<0.05)$.

Conclusion: The radiopacities of the tested sealers were above the minimum level recommended by ANSI/ADA Specification No. 57.
\end{abstract}

Key words: Radiopacity; root canal filling; digital radiography; sealer

\section{Resumo}

Objetivo: Avaliar a radiopacidade produzida por sete cimentos comercialmente disponíveis (AH Plus, Epiphany, Sealapex, Acroseal, Sealer 26, Endomethasone and Endofill) e um em estágio experimental (MBP). Metodologia: Depois de homogeneizados os materiais, o teste de radiopacidade foi executado conforme a especificação no 57 da ANSI/ADA. Radiografou-se os espécimes junto a uma escala de Alumínio e as imagens resultantes foram digitalizadas. As densidades radiográficas expressas em milímetros de Alumínio (mm Al) foram comparadas por meio da análise de variância e teste de Tukey $(\alpha=0.05)$.

Resultados: Os cimentos AH Plus (10 mm Al) e Epiphany ( $9 \mathrm{~mm} \mathrm{Al}$ ) apresentaram as maiores radiopacidades seguidos pelo Sealapex (8 $\mathrm{mm} \mathrm{Al})$, Endofill $(7 \mathrm{~mm} \mathrm{Al})$, Endométhasone $(7 \mathrm{~mm} \mathrm{Al}), \operatorname{MBP}(7 \mathrm{~mm} \mathrm{Al})$ e Sealer $26(6 \mathrm{~mm} \mathrm{Al})$. Acroseal $(5 \mathrm{~mm} \mathrm{Al})$ mostrou a menor radiopacidade entre os cimentos testados $(P<0.05)$.

Conclusão: Concluiu-se que as diferentes radiopacidades dos cimentos testados estão acima do nível mínimo recomendado pela especificação n 57 da ANSI/ADA.

Palavras-chave: Radiopacidade; obturação de canal radicular; radiografia digital; cimentos

\author{
Augusto Bodanezi a \\ Adriana Lustosa Pereirab \\ Etiene Andrade Munhoz ${ }^{c}$ \\ Norberti Bernardinelid \\ Ivaldo Gomes de Moraes d \\ Clovis Monteiro Bramante ${ }^{d}$
}

- Discipline of Endodontics, Federal University of Rio Grande do Sul, Porto Alegre, RS, Brazil b Discipline of Endodontics, Paulista University, Goiás, GO, Brazil

c Discipline of Pathology, Federal University of Rio Grande do Sul, Porto Alegre, RS, Brazil

dDiscipline of Endodontics, University of São Paulo, Bauru, SP, Brazil
Correspondence:
Augusto Bodanezi
Rua Ramiro Barcelos, 2492
Porto Alegre, RS - Brasil
90035-003
E-mail: aboda@usp.br
Received: June 26, 2009
Accepted: November 17, 2009 


\section{Introduction}

Sealing root canals hermetically is vital to maintain the disinfection achieved during chemomechanical preparation (1). Adequate obturation is only accomplished through the use of root canal sealers that are able to fill the spaces between gutta-percha cones, which the bulk of fillings fail to reach (2). For this reason, the type of root canal sealer may influence the radiographic images of root canal fillings (3). Radiopacity is a desirable quality for root canal filling materials because this property allows estimation of the length, width and deficiencies of the filling during radiographic analysis (3-6). The use of a material with a greater radiopaque quality might give the impression of a compact root canal obturation despite the presence of gross imperfections in the filling (4). Conversely, a less radiopaque material might be judged absent in areas where it is present in small amounts.

Many canal sealers are commercially available, and it is difficult to choose which one to use when their basic qualities are not known. In order to help the clinician in this process, this study compared the radiopacity of eight root canal sealers through the ANSI/ADA Specification No. 57 (6), which establishes the minimum levels for the clinical use of sealers.

\section{Methodology}

Eight root canal sealers were evaluated: AH Plus, Acroseal, Epiphany, Endomethasone, Sealer 26, Endofill, Sealapex and MBP. The commercial materials were mixed according to the manufacturers' instructions, with the exception that MBP components (epoxy resins, resin hardener, polyurethane polyol, calcium hydroxide, bismuth subnitrate and barium sulfate) were homogenized for $15 \mathrm{~s}$. The sealers were gently poured into metal rings ( $8 \mathrm{~mm}$ in diameter; $2 \mathrm{~mm}$ thick) and fixed on a flat glass covered with cellophane, taking care to prevent the formation of air bubbles in the mixtures. Another covered plate was then pressed onto the rings to standardize the specimen thickness. The filled rings/plate sets were transferred to an oven and kept at $37{ }^{\circ} \mathrm{C}$ for 72 hours to allow complete setting of the materials. The plates were then removed, and the specimen thickness was examined with a digital slide caliper (727 Starrett ${ }^{\mathbb{}}$, Itu, SP, Brazil). If required, the specimens were ground wet with 600-grit carbide paper (T277 Norton ${ }^{\circledR}$, Guarulhos, SP, Brazil) to reach an exact thickness of $2 \mathrm{~mm}$.

Specimens were arranged over occlusal radiographic films (Insight E, Eastman-Kodak Co., New York, EUA) and exposed near an aluminum stepwedge with variable thickness (from 1 to $10 \mathrm{~mm}$ in 1-mm increments). An X-ray unit (Kaycor X-707 Yoshida, Tokyo, Japan) operating at $70 \mathrm{kVp}, 7 \mathrm{~mA}$ and $0.35 \mathrm{~s}$ was employed. The exposure was taken at a focus-film distance of $35 \mathrm{~cm}$.

The pellicles were developed by the temperature-time method, and the radiographs obtained were digitized in a scanner (Colour Vivid 3 Slim, Genius, Taiwan) set at a resolution of 1200 dpi. The resulting TIFF files were transferred to public-domain software (Image J 1.41v, Waine Rasband, National Institute of Health, USA), and the mean gray values (in pixels) of the area inside the rings and that corresponding to the increasing thickness of the aluminum stepwedge were measured with the histogram tool (Fig. 1). The pixel values and aluminum thicknesses were analyzed by a one-way analysis of variance (ANOVA) with Tukey's test for multiple comparisons, at the 5\% significance level.

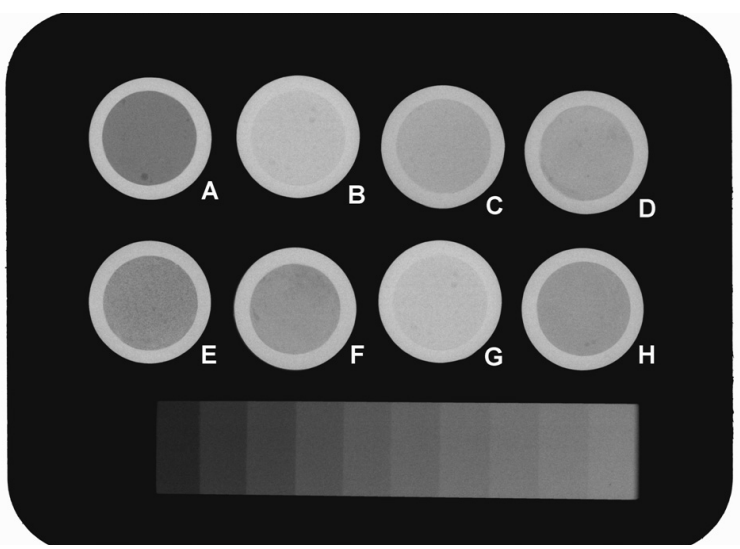

Fig. 1. Representative radiography of test samples near the aluminium stepwedge (bottom): a - Acroseal; b - Endofill; c - Epiphany; d - Sealapex; e - Sealer 26; f - Endomethasone; g - AH Plus; $h$ - MBP.

\section{Results}

Figure 2 illustrates the mean pixel values, standard deviations and significant differences among the groups. AH Plus (179.3 \pm 10.2$)$ and Epiphany (163.0 \pm 8.9$)$ presented similar radiopacity values (10 and $9 \mathrm{~mm} \mathrm{Al}$, respectively) which were significantly higher than those for the other sealers. The radiopacity of Sealapex $(156.3 \pm 4 ; 8 \mathrm{~mm} \mathrm{Al})$ was the same as that of Endofill $(152.1 \pm 5.8 ; 7 \mathrm{~mm} \mathrm{Al})$. Both materials were significantly more radiopaque than Sealer $26(130.5 \pm 5.2 ; 6 \mathrm{~mm} \mathrm{Al})$, which showed a mean pixel value that was statistically equivalent to those of Endomethasone $(140 \pm 9.7 ; 7 \mathrm{~mm} \mathrm{Al})$ and $\mathrm{MBP}(139.3 \pm 9.4 ; 7 \mathrm{~mm} \mathrm{Al} ; P<0.05)$. Acroseal $(117.4 \pm 4.1 ; 5 \mathrm{~mm} \mathrm{Al})$ had the lowest radiopacity among the tested sealers $(P<0.05)$.

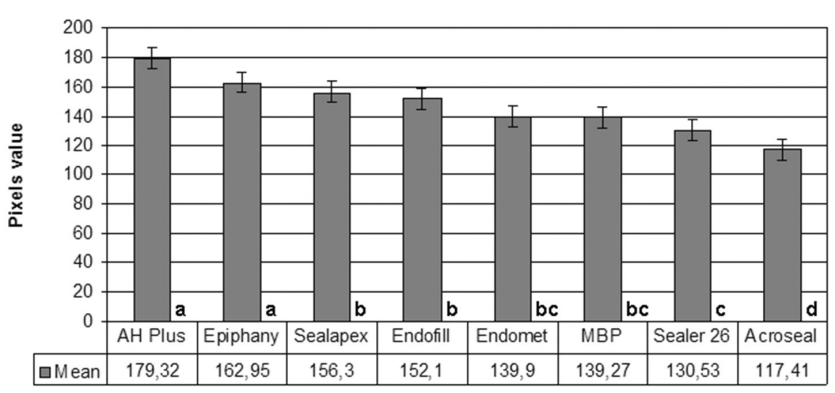

Fig. 2. Radiopacity (mean and standard deviation) of the tested materials (same letters indicate statistical equivalence, $P<0.05$ ). 


\section{Discussion}

The quantification of mean pixel values obtained from digital radiographs supports the direct comparison by statistical tests. However, the radiopacity of root canal filling materials is routinely expressed in millimeters of aluminum, as recommended by ANSI/ADA Specification No. 57 (6) and ISO 6876 (7). In this investigation, the conversion of mean pixel values to corresponding millimeters of aluminum was executed by a previously described method (8-10). The test does not generate decimal values of aluminum stepwedge thicknesses; therefore, corresponding intermediary levels were calculated using mathematical formulas or correlation graphics (11-16).

The lower radiopacity of Epiphany compared to AH Plus has been reported previously $(12,17)$. This result is likely due to differences in the radiopacity potential of specific components, similar as the effects observed when bismuth oxide (present in Epiphany) and zirconium oxide (present in AH Plus) are added individually to pure Portland cement (16). When evaluating zinc-oxide eugenol sealers, the powder/ liquid ratio chosen directly influenced the in vitro radiopacity (18). Because manufacturers do not explicitly state the correct powder/liquid ratio, the larger amounts of Endomethasone and Endofill powder added to liquids may explain the radiopacity differences in this research compared to others $(9,10,13,19)$. These discrepancies in the powder/ liquid ratio may also explain the differences detected for the radiopacity contrast of Sealer 26 compared to the literature $(11,13,20,21)$, but further investigation is required to confirm this hypothesis.

Recently, the formula of Sealapex was modified, and barium sulfate was replaced by bismuth trioxide (a more efficient radiopaque agent) (15). This alteration likely caused an increase in the radiopacity of this sealer, which could justify its radiographic superiority compared to the zinc oxide sealers and Sealer 26. This result was not observed in former investigations $(8,11,13,19)$.

MBP is currently under testing, and this product was found to be more radiopaque in the present study than in previous works $(10,20)$. Due to its paste/paste presentation, the ratio of radiopaque agents may justify this distinction. Another explanation for this result lies in methodological differences in the radiopacity testing assays.

In the study by Duarte et al. (16), the radiopacifying agent of AH Plus (zirconium oxide) was added alone to Portland cement. The resulting radiopacity was comparable to that obtained by the addition of bismuth carbonate, the radiopaque element present in Acroseal. Because a marked difference between AH Plus and Acroseal radiopacities was detected in this study and in that by Tanomaru et al. (15), we speculate that extra low-radiopacity substances (e.g., calcium tungstate and iron oxide) may be present in the formula of AH Plus. If this hypothesis were confirmed, it would also justify the differences observed between this sealer and Endofill $(12,13,21,22)$, Sealapex $(8,11,13)$ and Sealer $26(13,21)$.

According to the American National Standards Institute/ International Standard Organization (7) and American Dental Association (ANSI/ADA) Specification No. 57 (6), endodontic filling materials should present a difference equivalent to at least $2 \mathrm{~mm}$ of aluminum when compared to bone or dentin in order to be distinguished by radiography. In this investigation, all sealers presented radiopacity levels above the minimum ( $3 \mathrm{~mm}$ of aluminum) recommended level. Thus, all are theoretically approved for clinical use. However, it should be noted that sealer thicknesses established clinically between radiopaque gutta-percha cones during root canal filling procedures might differ from those established by the current protocols. For this reason, the applicability of these results to an actual clinical situation remains uncertain until more realistic radiopacity tests are conducted.

\section{Conclusions}

All of the root canal sealers tested presented different radiopacities. All radiopacities were above the minimum $3 \mathrm{~mm}$ of Al recommended by ANSI/ADA Specification No. 57 for clinical use.

\section{References}

1. Peters LB, Wesselink PR, Moorer WR. The fate and the role of bacteria left in root dentinal tubules. Int Endod J 1995;28: 95-9.

2. Wu M-K, Fan B, Wesselink PR. Diminished leakage along root canals filled with gutta-percha without sealer over time: a laboratory study. Int Endod J 2000;33:121-5.

3. Baksi $A B G$, Eyüboğlu TF, Sen BH, Erdilek N. The effect of three different sealers on the radiopacity of root fillings in simulated canals. Oral Surg Oral Med Oral Pathol Oral Radiol Endod 2007; 103:138-41.

4. Beyer-Olsen EM, Ørstavik D. Radiopacity of root canal sealers. Oral Surg Oral Med Oral Pathol 1981;51:320-8.
5. van der Sluis LWM, Wu M-K, Wesselink PR. An evaluation of the quality of root fillings in mandibular incisors and maxillary and mandibular canines using different methodologies. J Dent 2005;33:683-8.

6. American National Standards Institute. American Dental Association. Specification no. 57 - Endodontic sealing materials: 2000. Chicago; 2000.

7. International Organization for Standardization. ISO TC/106, ISO/CD 6876 - Dental root canal sealing materials: 2001. Geneva; 2001.

8. Costa RF, Scelza MFZ, Costa AJO. Radiopacidade de cimentos endodônticos: avaliação pela intensidade pixel. JBC J Bras Clin Odontol Integr 2002;6:137-9. 
9. Deonizio MDA, Gabardo MCL, Silva WJ, Tsuda LM, Rached RN Silva Neto UX. Avaliação das propriedades físico-químicas de cimentos obturadores de canais radiculares. Rev Bras Odontol 2003;60:353-6.

10. Moraes IG, Bramante CM, Moraes FG, Gonçalves SB, Mori GG. Avaliação da radiopacidade dos cimentos endodônticos Sealer 26, Endofil e de um cimento experimental. J Bras Endod 2006; 6:8-12.

11. Tagger M, Katz A. Radiopacity of endodontic sealers: development of a new method for direct measurement. J Endod 2003;29: 751-5.

12. Carvalho-Junior JR, Correr-Sobrinho L, Correr AB, Sinhoreti MA, Consani S, Souza-Neto MD. Radiopacity of root filling materials using digital radiography. Int Endod J 2007;40:514-20.

13. Tanomaru JMG, Cezare L, Gonçalves M, Tanomaru Filho M. Evaluation of the radiopacity of root canal sealers by digitization of radiographic images. J Appl Oral Sci 2004;12:355-7.

14. Tanomaru-Filho $M$, Jorge EG, Tanomaru JMG, Gonçalves $M$. Radiopacity evaluation of new root canal filling materials by digitalization of images. J Endod 2007;33:249-51.

15. Tanomaru-Filho M, Jorge EG, Tanomaru JMG, Gonçalves $M$. Evaluation of the radiopacity of calcium hydroxide- and glassionomer-based root canal sealers. Int Endod J 2008;41:50-3.
16. Duarte MAH, El-Kadre GDO, Vivan RR, Tanomaru JMG, TanomaruFilho M, Moraes IG. Radiopacity of portland cement associated with different radiopacifying agents. J Endod 2009;35:737-40.

17. Tasdemir T, Yesilyurt C, Yildirim T, Er K. Evaluation of the radiopacity of new root canal paste/sealers by digital radiography. J Endod 2008;34:1388-90.

18. Camps J, Pommel L, Bukiet F, About I. Influence of the powder/ liquid ratio on the properties of zinc oxide-eugenol-based root canal sealers. Dent Mater 2004;20:915-23.

19. Ferreira FBA, Silva e Souza PAR, Vale MS, Tavano O. Radiopacidade de cimentos endodônticos avaliados pelo sistema de radiografia digital. Rev FOB 1999;7:55-60.

20. Brandão CG. Propriedades físico-quimicas dos cimentos endodônticos resinosos Sealer 26, e dos experimentais, Sealer Plus e MBP, comparadas às do óxido de zinco e eugenol [thesis]. Bauru (SP): Faculdade de Odontologia da Universidade de São Paulo; 1999.

21. Lisboa FM, Kopper PMP, Figueiredo JAP, Tartarotti E. Estudo da radiopacidade de três cimentos endodônticos por meio da imagem digitalizada. J Bras Endod 2003;4:193-7.

22. Sydney GB, Ferreira M, Leonardi DP, Deonizio MDA, Batista A. Analysis of the radiopacity of endodontic sealers using a digital radiograph system. Rev Odonto Ciênc 2008;23:338-41. 